\title{
Perancangan $E$ - Learning Beladiri Praktis Bagi Mahasiswi UHAMKA Guna Menghindari Kejahatan Dan Pelecehan Seksual Berbasis Moodle
}

\author{
Hasan Dhiaulhaq Thalib ${ }^{1)}$, \& Isa Faqihuddin Hanif ${ }^{2)}$ \\ ${ }^{1,2)}$ Universitas Prof. Dr. Hamka \\ Jl. Tanah Merdeka No.6, RT.10/RW.3, Rambutan, Kec. Ps. Rebo, Kota Jakarta Timur, 13830 Telp (021) 87782739 Fax - \\ Mobile 0858-1300-1800 \\ Website: ft.uhamka.ac.id/ ,E-mail: hasan23071997@gmail.com
}

\begin{abstract}
Abstrak - Teknologi saat ini mengalami kemajuan yang pesat pada kalangan masyarakat, tentu sebagai masyarakat yang mengikuti perkembangan zaman harus selalu up to date untuk teknologi, apalagi dalam proses pembelajaran untuk siswa dan siswi yang dimana hari di tahun yang sulit ini tahun 2020 banyak siswa belajar melalui proses E- Learning, maka dari itu penulis mencoba untuk merancang program pembelajaran berbasiskan moodle. moodle sebagai alat penunjang untuk membuat elektronik learning yang dimana metode pembelajaran beladiri tidak hanya di lakukan melalui tatap muka saja, maka dari itu penulis coba mengembangkan dengan cara belajar secara virtual dan mobile, penelitian ini bertujuan untuk menerapkan teknologi informasi bagi para siswa untuk mempelajari seni beladiri praktis sebagai metode pertahanan diri dari segala marabahaya disekitar kita, system yang dirancang oleh penulis merupakan system yang mudah dan praktis yang dapat di akses oleh banyak orang, dikarenakan moodle saat ini berkembang pesat dengan berbagai variasi metode pembelajaran bagi yang menggunakannya sebagai bentuk pembelajaran virtual, selain mudah diakses dan mudah dipelajari sebagai admin bisa dapat mengunakan aplikasi moodle tersebut, dikarenakan penggunaannya tidak terlalu rumit uuntuk di pelajari, dan dapat menyimpan database pembelajaran melalui localhost/phpmyadmin/ sebagai bahan untuk menyimpan dan membuat database pembelajaran moodle. Perancangan ini menggunakan metode waterfall sehingga mudah untuk membantu orang lain bagaimana menggunakan moodle tersebut.
\end{abstract}

Kata kunci: Beladiri Praktis, e-learning Moodle, Web

\begin{abstract}
Abstrak - Technology is currently experiencing rapid progress in the community, of course as a society that keeps up with the times, it must always be up to date for technology, especially in the learning process for students and schoolgirls, where in this difficult year in 2020 many students learn through the E process. -Learning, therefore the author tries to design Moodle-based learning programs. Moodle as a supporting tool for making electronic learning, where the self-defense learning method is not only done face-to-face, therefore the authors try to develop it by learning virtual and mobile, this study aims to apply information technology for students to learn practical martial arts as a method of self-defense from all the dangers around us, the system designed by the author is an easy and practical system that can be accessed by many people, because Moodle is currently developing. rapidly with a variety of learning methods for those who use it as a form of virtual learning, in addition to being easily accessible and easy to learn as an admin, you can use the Moodle application, because its use is not too complicated to learn, and can save data. tabase learning via localhost / phpmyadmin / as material to store and create a Moodle learning database. This design uses the waterfall method so that it is easy to help others how to use the moodle.
\end{abstract}

Keywords: E-learning, Moodle, Practical Self-defense, Web

\section{PENDAHULUAN}

Tingkat kriminal saat ini sangat meresahkan dikalangan masyarakat dan kejahatan merajalela dimana-mana dengan metode kejahatan yang berbeda beda seperti pencurian, pembunuhan, pemerkosaan bagi kaum wanita atau pelecehan seksual, beladiri diperlukan untuk memproteksi diri ancamanancaman kejahatan tersebut, selain untuk meminimalisir tindak kejahatan juga tentunya, banyak beladiri yang dapat dipelajari saat ini seperti taekwondo, karate, kungfu, dan beladiri dari indonesia yaitu Pencak silat, kurangnya informasi tentang perguruan beladiri tersebut penulis mencoba 
untuk melakukan inovasi berupa pembelajaran beladiri praktis dengan basic pencak silat berbasis. Sistem informasi mengalami perkembangan yang sangat pesat sehinga dapat dengan mudah di akses, bagi para pelajar atau mahasiswa serta masyarakat diharuskan untuk memanfaatkan dan mengembangkan berbagai macam teknologi tersebut, pemanfaatan teknologi informasi pembelajaran sangat tidak membosankan, menjadi lebih menarik, mudah dipahami dan dapat di akses di manapun dan kapanpun ketika tersambung dengan jaringan internet. E-learning yang merupakan singkatan dari Electronic Learning merupakan cara baru yang dilkakukan pada zaman ini untuk melakukan suatu pembelajaran dalam bentuk digital baik secara bentuk isi maupun sistem yang ada pada $e$ - learning tersebut. Sejalan dengan perkembangan tersebut, banyak kegiatan yang dilakukan dengan teknologi ini guna mempemudah metode pembelajaran jarak jauh ataupun dekat, karena penyajiannya dalam bentuk mater pembelajaran kedalam internet yang sangat mudah untuk diakses bagi kalangan pelajar supaya tidak perlu lagi bertatap muka dengan guru atau dosen untuk metode pembelajaran yang lebih efektif dan relevan, teknologi belajar seperti itu bisa juga disebut sebagai belajar atau pembelajaran berbasis Web (web based instruction).

Pencak silat ialah seni beladiri dari Asia yang berakar dari budaya melayu, pencak silat yang mengandung unsur keislaman seperti Pagar Nusa, Cepedi dan Tapak Suci. Perguruan seni beladiri Tapak Suci adalah sebuah aliran, perguruan dan organisasi yang merupakan anggota Ikatan Pencak Silat Indonesia (IPSI). Tapak Suci berdiri pada tanggal 10 Rabiul Awal $1383 \mathrm{H}$ atau bertepatan pada tanggal 31 juli 1963 di kauman, Yogyakarta.

Beladiri adalah sebuah olahraga yang mampu membawa pelajaran untuk menghindari sebuah kejahatan, beladiri juga merupakan salah satu upaya juga terhidar dari segala jenis pelecehan seksuan terutama untuk kauh perempuan yang dimana membutuhkan perlindungan diri sebagai jenis bentuk pertahanan diri. Seiring perkembangan zaman ini pembelajaran beladiri juga harus mengikuti alur yang dimana berada di era 4.0, merupakan era globalisasi yang semuanya berbasis mobile. Pembelajaran beladiri juga bisa dilakukan secara online melalui sistem informasi yang akan di buat berbasis moodle ini $e$ - learning pada pembelajaran beladiri praktis berbasis moodle sangatlah mudah untuk di pelajari oleh pengguna gadget atau smartphone karna sangatlah mudah untuk mengakses informasi dan juga mudah untuk di praktekan ketika senggang, di dalam fitur- fitur pembelajaran beladiri praktis ada sebuah ulasan serta tata cara mempertahankan diri dari serangan serangan musuh ketika dalam keadaan bahaya, melainkan konsep dasar beladiri juga ada teori dan tutorial pergerakan ketika dalam posisi yang terdesak, sehingga tutorial pergerakan spontan ada dalam metode pembelajaran beladiri praktis ini berbasis moodle.

\section{LANDASAN TEORI}

\subsection{E-LEARNING}

e-learning merupakan sebuah singkatan dari kata Electronic dan Learning, Pada saat ini Electronic learning banyak digunakan untuk proses belajar mengajar dan merupakan metode baru pada zaman ini, proses belajar mengajar yang menggunakan media elektronik sebagai sistem pembelajarannya. Universitas Illionis di Urbana-Champaign adalah yang pertama kali memperkenalkan e-learning dengan menggunakan sistem instruksi berbasis komputer atau bisa disebut dengan computer assisted instruction dan juga menggunakan komputer yang bernama PLATO. Berawal dari penggunaan sistem tersebut, sistem e- learning terus berkembang sejalan dengan perkembangan dan kemajuan ICT Pada saat ini sudah banyak dilakukannya penelitian dalam mencari manfaat atau kelebihan dari e-learning untuk proses pengembangannya. Karena e-Learning dianggap sebagai salah satu metode yang terbaik dalam dunia pembelajaran. Berikut ini kelebihan dari penerapan $e$ - learning dalam dunia pembelajaran.:

1. Sangat fleksibel ketika mempertimbangkan masalah waktu dan tempat. Setiap perserta didik memiliki kebebasan dalam memilih tempat dan waktu yang cocok untuknya. Menurut Smedley (2010), penerapan e-learning memberikan banyak fleksibilitas waktu dan tempat bagi lembaga maupun perserta didik dalam melakukan proses pembelajaran.

2. e-learning meningkatkan keberhasilan pengetahuan dan memberikan kemudahan menggunakan akses untuk sejumlah besar informasi yang dibutuhkan.

\subsection{MOODLE}

Moodle adalah suatu perangkat lunak yang bersifat open source yang dapat mendukung implementasi 
dari e-learning dengan berbagai fitur yang dapat menunjang sistem pembelajaran dengan mudah dan dapat diakomodari salam suatu portal e-Learning. Fitur penting yang dimaksud dapat menunjang system pembelajaran tersebutmisalnya adalah tugas, quiz, kolaborasi,komunikasi dan juga fitur yang utama yaitu dapat mengunggah berbagai format menjadi materi pembelajaran.Moodle adalah suatu singkatan yang terdiri dari Modular Object-Oriented Dynamic Learning Environment yang memiliki arti tempat belajar yang dinamis dengan menggunakan metode berorientasi objek. Dalam penyediaannya, Moodle memberikan paket software yang lengkap (Moodle + Apache + MySQL + PHP). Moodle adalah paket software yang diproduksi untuk kegiatan belajar berbasis internet dan Website dan terus mengembangkan rancangan sistem dan desain user interface setiap minggunya (up to date). Moodle tersedia dan dapat digunakan secara bebas sebagai produk open-source dibawah lisnesi GNU (General Public License).

\subsection{BELADIRI PENCAK SILAT}

Pencak silat merupakan salah satu beladiri warisan budaya dari indonesiayang ada sejak dahulu diturunkan secara turun temurun dari generasi ke generasi dan merupakan salah satu identitas dari bangsa indonesia, budaya dari pencak silat merupakan aspek penting istilah pencak pada umumnya menggambarkan tentang tarian, music dan busana tradisional dari indonesia dan aspek dari beladiri pencak silat adalah kepercayaan dan ketekunan untuk menguasi beladiri tersebut dan silat merupakan istilah dari kemampuan teknis beladiri pencak silat. Selain itu ada aspek olahraga dalam mempelajari pencak silat berupa pengolahan fisik dan mental yang kuat supaya mampu mengimbangi pikiran dan olahan tubuh

Ilmu beladiri telah lama dikenal oleh bangsa indonesia, bahkan berpuluh puluh tahun sebelum indonesia merdeka, ilmu beladiri merupakan ilmu untuk kesejahteraan dunia dan akhirat yang berdasarkan prinsip-prinsip beladiri, yaitu membela diri sendiri dan juga dapat membela orang lain. Pencak silat ialah seni beladiri dari Asia yang berakar dari budaya melayu, pencak silat yang mengandung unsur keislaman seperti Pagar Nusa, Cepedi dan Tapak Suci. Perguruan seni beladiri Tapak Suci adalah sebuah aliran, perguruan dan organisasi yang merupakan anggota Ikatan Pencak Silat Indonesia (IPSI). Tapak Suci berdiri pada tanggal 10 Rabiul
Awal $1383 \mathrm{H}$ atau bertepatan pada tanggal 31 juli 1963 di kauman, Yogyakarta

Selain budaya indonesia, pencak silat juga merupakan beladiri untuk membentuk diri supaya kita yang mempelajari beladiri dapat mempertahankan diri dari segala serangan kejahatan, minimal untuk meminimalisir tindak kejahatan yang akan dilalui.

\section{METODOLOGI PENELITIAN}

\subsection{Skema Alur Penelitian}

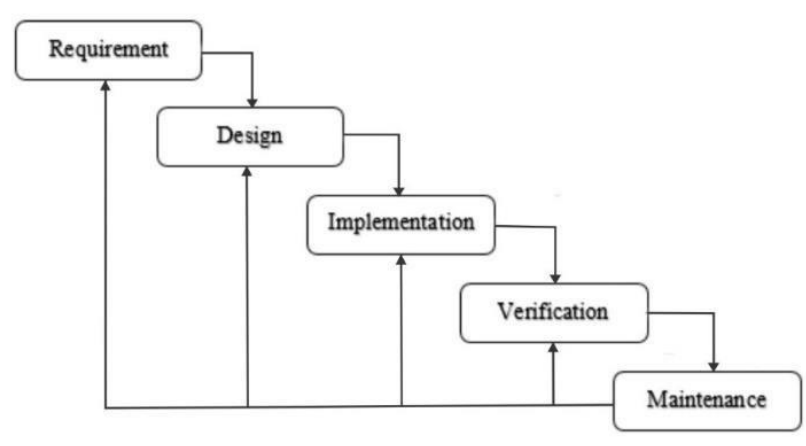

Gambar 1 Skema Alur Pendaftaran

\subsubsection{Identifikasi Masalah}

Pada tahap ini akan melakukan identifikasi masalah pada pembelajaran beladiri praktis untuk mengetahui apa saja permasalahan yang dialami oleh individu sebagai pelajar untuk mendapatkan materi pembelajaran dalam beladiri praktis. Dan dari masalah tersebut terdapat analisis apa yang kurang untuk mempelajari materi dalam pembelajaran beladiri praktis dan untuk mengatasi masalah yang ada.

\subsubsection{Perancangan sistem}

Pada tahap ini penulis bertujuan untuk membuat skema perancangan sistem dan analisis sistem dari hasil pengolahan data yang sudah didapat sehingga bisa menjadi acuan untuk tahap pembuatan sistem. Perancangan dan analisis sistem meliputi membuat diagram serta konsep sistem secara keseluruhan untuk membuat sistem pembelajaran e-learning untuk beladiri praktis berbasis Moodle. 


\subsubsection{Pembuatan Sistem}

Tahap ini merupakan tahap pembuatan dan pengembangan dari sistem pembelajaran $e$ Learning yang dibuat berdasarkan hasil perancangan yang sudah ditetapkan pada tahap sebelumnya. Tool yang digunakan dalam pembuatan sistem e-Learning ini adalah MOODLE (Modular Object-Oriented Dynamic Learning Enviroment) dengan software pendukung yaitu XAMPP meliputi PHP Programming dan database $M Y S Q L$.

\subsubsection{Pengujian Sistem}

Setelah sistem sudah selesai dibuat dan materimateri yang dibuat sudah dimasukan kedalam sistem, pada tahap ini dilakukannya pengujian terhadap sistem. Sistem yang akan diujikan sebagai bentuk berhasil atau tidakna siste tersebut akan diujikan dengan metode blackbox testing dan whitebox testing, maka dari itu dapat diketahui apakah sistem berjalan dengan baik atau tidak.

\subsection{Jenis Dan Teknik Pengumpulan Data}

Tahap ini penulis mencari informasi yang akan dijadikan sebuah data untuk melakukan penelitian ini.

Adapaun metode yang akan digunakan penulisan dalam pengumpulan data-data yaitu.

\section{Teori}

Pada metode ini peneliti melakukan pencarian dan pembelajaran dari berbagai macam buku, jurnal, maupun artikel-artikel yang berkaitan dengan $e$ Learning, beladiri praktis, serta aplikasi-aplikasi yang digunakan dalam penelitian ini sebagai bahan referensidalam penyusunan laporan.

\section{Pengamatan Pembelajaran}

Metode ini merupakan pengumpulan data yang dilakukandengan mengamati dan melihat proses pembelajaran pada drums secara langsung maupun melalui media yang terdapat pada internet, bertujuan untuk menentukan bagaimana penyusunan materi yang tepat untuk dilakukannya pembelajaran pada beladiri.

\section{Wawancara}

Penulis melakukan pengumpulan data dengan menggunakan metode wawancara yang tidak terstuktur, tidak menggunakan pedoman wawancara yang berisi pertanyaan-pertanyaan spesifik, namun Copyright (C) 2020 FT-UHAMKA. - All rights reserved DOI: 10.22236/teknoka.v5i.340 hanya memuat poin-poin penting mengenai pertanyaan seputar kejahatan dan cara menyikapinya

\section{HASIL DAN PEMBAHASAN}

Hal yang paling utama dalam proses installasi MOODLE yaitu sudah menyiapkan ataupun menginstall aplikasi XAMPP. Jika aplikasi XAMPP sudah terinstall, jalankan aplikasi $X A M P P$ atau $X A M P P$ Control Panel, lalu tekan "Start" pada Apache dan $M y S Q L$, maka tombol akan berubah menjadi "Stop" seperti gambar.

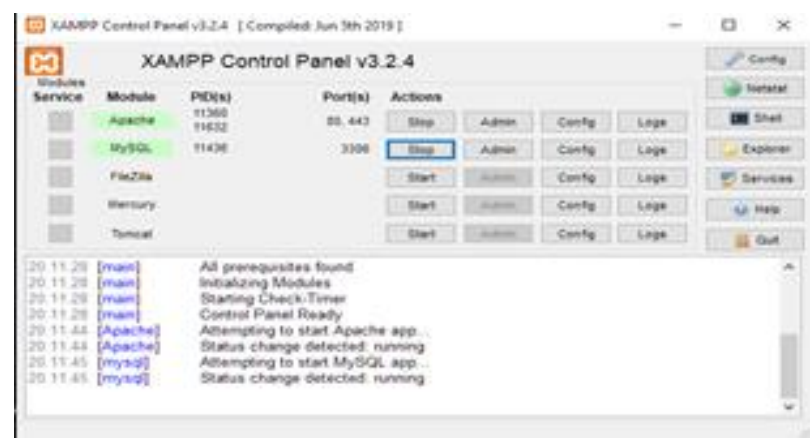

Gambar 2 Tampilan XAMPP

Moodle dapat diunduh pada situs resminya yaitu https:/moodle.org. Extract berkas moodle yang telah diunduh, pada kali ini penulis mengubah nama folder yang telah di-extract menjadi "beladiripraktis", kemudian pindahkan folder tersebut kedalam folder xampp\htdocs ,

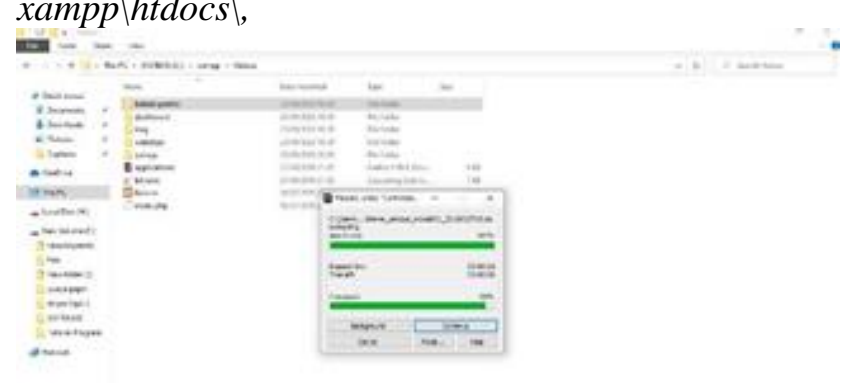

Gambar 3 Ekstrak File Moodle kedalam htdoc

Setelah selesai extrak folder kedalam htdoc buka aplikasi browser untuk melanjutkan proses penginstalan moodle online, lalu ketikan "localhost//moodle" lalu akan muncul tampilah halaman awal. 


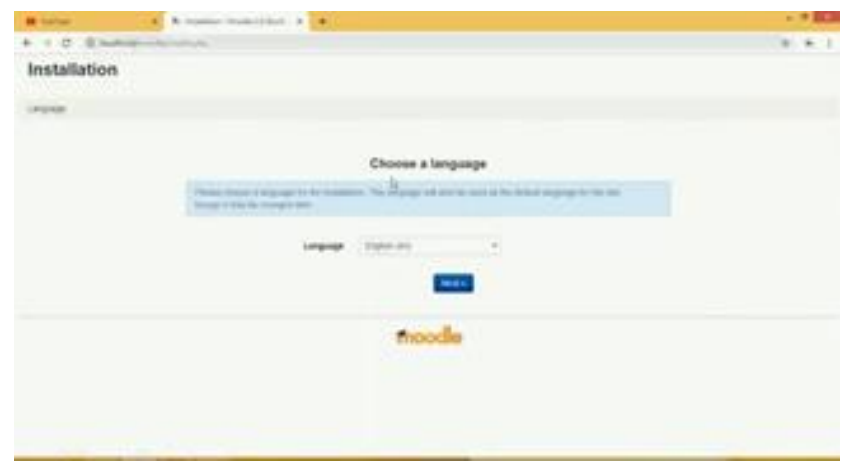

Gambar 4 Tampilan Awal Instalasi Moodle

Memilih bahasa yang di inginkan untuk lebih mempermudah proses pembelajaran lalu tekan "Next" maka akan masuk kehalaman selanjutnya yaitu merupakan halaman Confirm Pathspada halaman masukan alamat website, dikarenakan penulis menggunakan localhost dan sudah sesuai dengan tampilan, lalu tekan "Next" untuk melanjutkan proses.

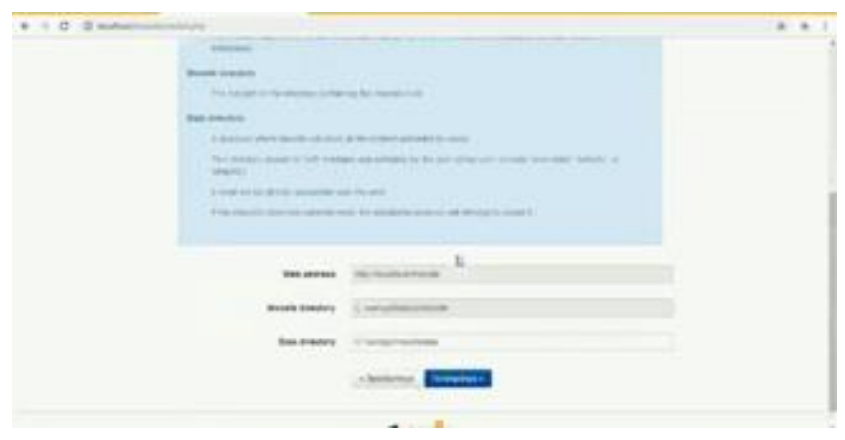

Gambar 5 Tampilan Confirm Path

Setelah halaman Confirm Paths akan dialihkan pada halaman selanjutnya yaitu halaman Database Driver, pilih tipe database yang digunakan kemudian tekan "Next" halaman sesuai dengan jumlah halaman yang

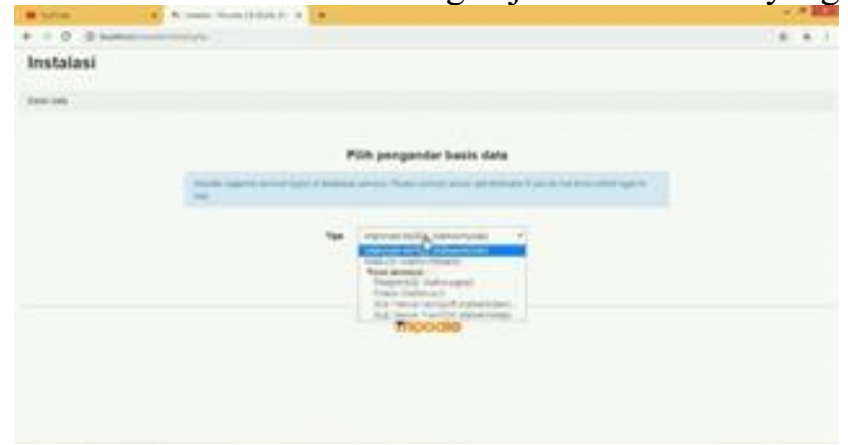

Gambar 6 Tampilan Database Driver

Halaman selanjutnya adalah Database Setting. Pada halaman ini akan mengisi pengaturan dari database

Copyright $\left({ }_{0} 2020\right.$ FT-UHAMKA. - All rights reserved DOI: 10.22236/teknoka.v5i.340 yang digunakan, yang perlu diisi adalah database user yang diisi dengan "root", untuk kolom yang lainnya biarkan seperti yang sudah tertera. Untuk pengaturan database.

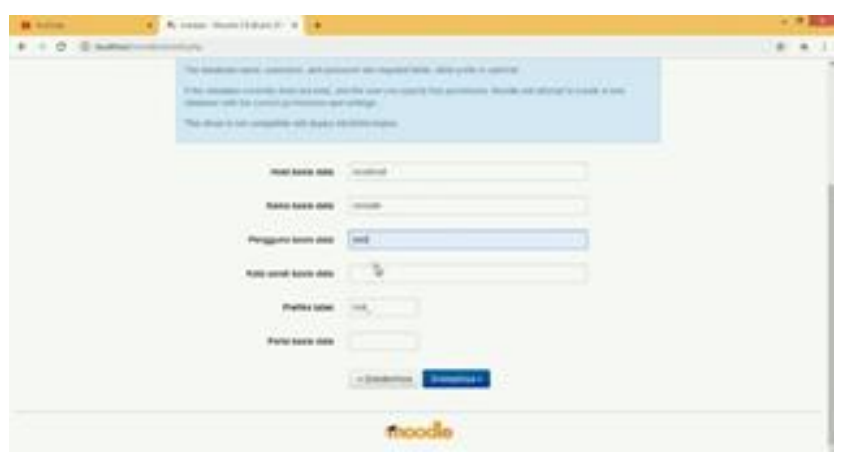

Gambar 7 Tampilan Database Setting

Setelah selesai mengatur database, halaman selanjutnya adalah Server Checks

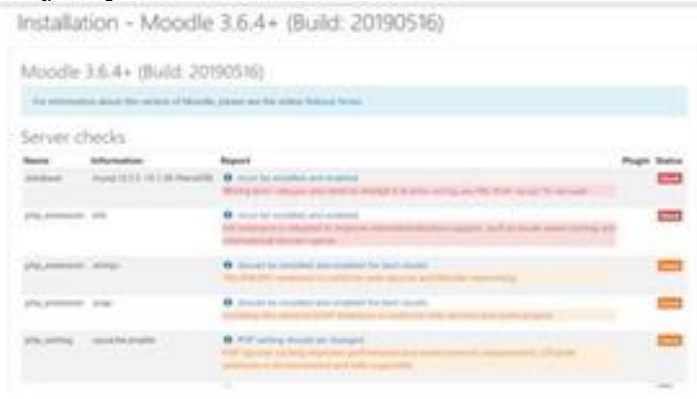

Gambar 8 Tampilan Server Check

Pada tampilan server check ada beberapa pengaturan yang belum di konfigurasi maka pada gambar 4.7 sebaiknya konfigurasi file terlebih dahulu untuk dapat melakukan proses selanjutnya, setelah konfirgurasi benar seanjutnya anda klik continue untuk melanjutkan proses instalasi

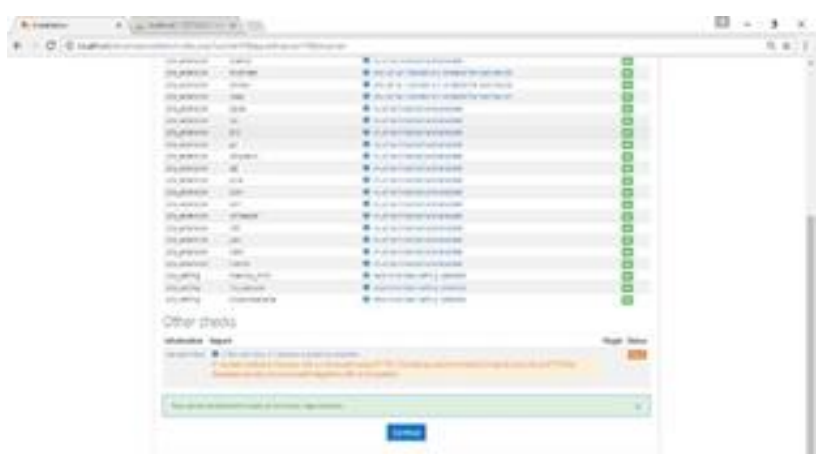

Gambar 9 Tampilan server check sudah benar

Tunggu proses instalasi berjalan sampai dengan selesai, setelah proses instalasi selesai nanti akan Seminar Nasional TEKNOKA ke - 5, Vol. 5,2020 ISSN No. 2502-8782 
ada tulisan continue lalu klik tulisan "continue untuk lanjut kehalaman berikutnya

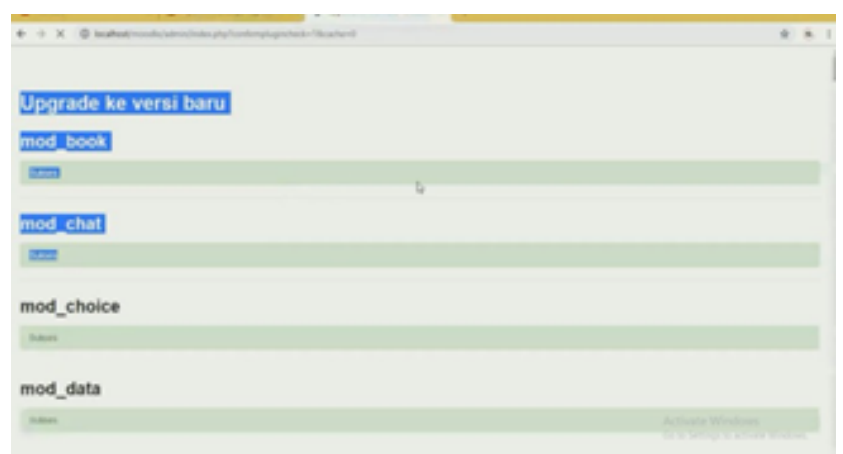

Gambar 10 Proses Instalasi

Setelah proses instalasi selesai lalu klik "continue" untuk masuk pada halaman pendaftaran formulir untuk admin. Isi data pada kolom yang telah disediakan, untuk yang terdapat tanda ! (seru) maka menandakan keharusan untuk mengisi kolom tersebut. Jika formulir sudah diisi maka klik "Update Profile"

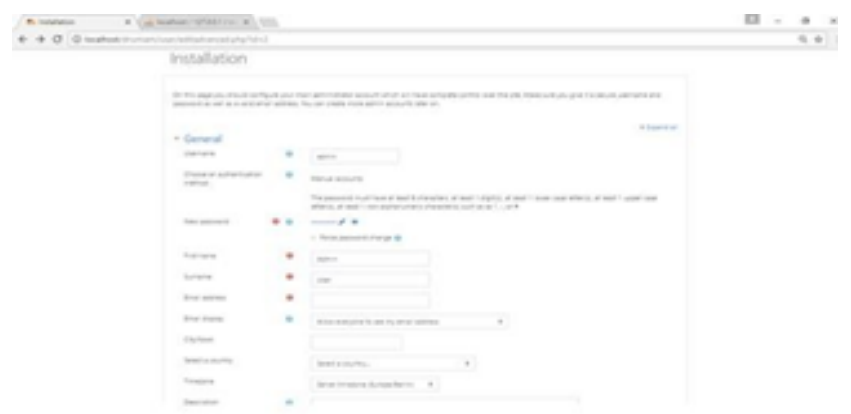

Gambar 11 Pendaftaran untuk Admin

Langkah selanjutnya adalah mengisi profil dan melakukan pengaturan pada Front Pagee-Learning yang akan ditampilkan. Jika sudah selesai mengisi profil dan melakukan pengaturan, tekan "Save Changes"

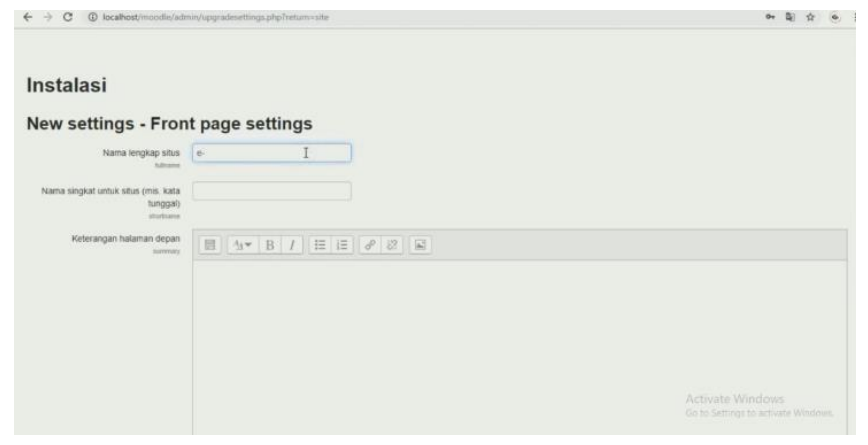

Gambar 12 setting front page

Copyright (C) 2020 FT-UHAMKA. - All rights reserved DOI: 10.22236/teknoka.v5i.340
Setelah melakukan pengaturan pada Front Page maka akan muncul halaman utama dari website $e$ learning seperti pada gambar yang menandakan bahwa Moodle telah berhasil terinstal

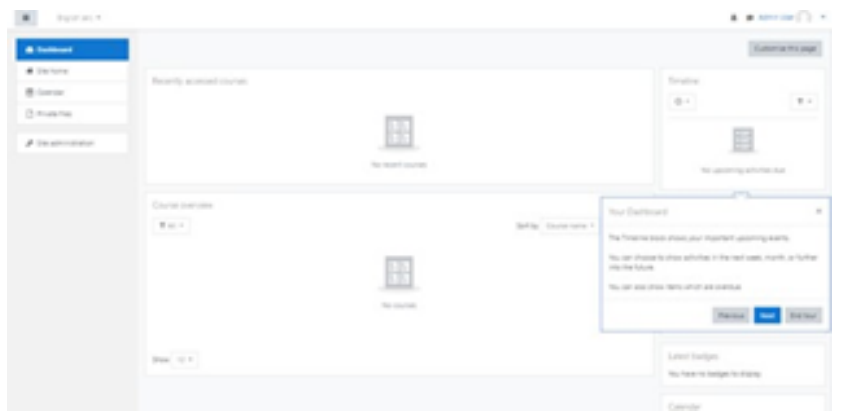

Gambar 13 Halaman Utama Website E-Learning

Berikut merupakan tampilan halaman awal pada sistem pembelajaran e-Leraning. Terdapat beberapa kelas kursus yang tersedia didalam sistem pembelajaran e-Learning tersebut. Jika memilih salah satu dari kelas kursus tersebut, kita akan dialihkan terlebih dahulu ke halaman login. Terdapat tombol login untuk berpindah halaman ke halaman login

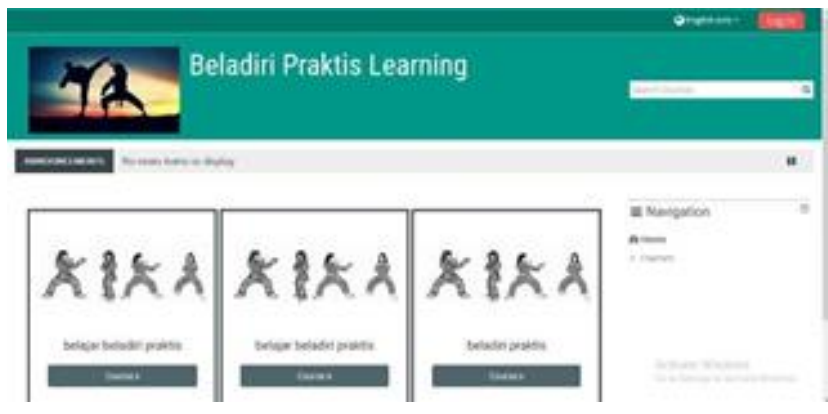

Gambar 14 Tampilan Awal Login

Berikut merupakan tampilan halaman login. Pada halaman login terdapat text input yang digunakan untuk memasukkan username dan password user yang sudah terdaftar di dalam sistem e-Learning. Terdapat button login, button Masuk sebagai tamu, button Daftar untuk menjadi anggota baru. Jika memilih daftar untuk menjadi anggota baru maka akan dialihkan ke halaman pendaftaran untuk anggota baru. Jika kita memilih masuk sebagai tamu, maka akan dialihkan ke halaman utama dengan peran hanya sebagai tamu, dimana tamu ini hanya dapat melihat konten ataupun materi yang diizinkan oleh admin maupun pelatih dalam pencarian. Kolom search digunakan untuk 
pencarian nama karyawan secara lebih detail. Dan icon print, untuk export data kedalam bentuk pdf.
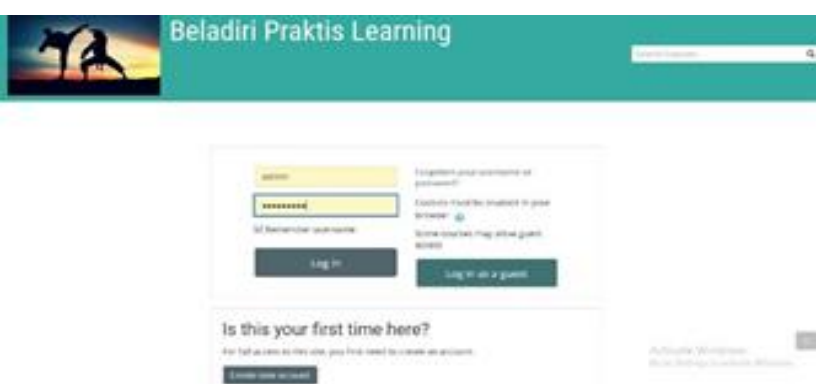

Gambar 15 Antarmuka Halaman Login

Berikut merupakan tampilan halaman saat melakukan pendaftaran. Pada tampilan pendaftaran pengguna baru, terdapat beberapa text inputyang digunakan untuk mengisi data-data pengguna baru sebagai persyaratan mendaftar menjadi anggota baru dan terdapat combo box yang digunakan untuk memilih negara tempat tinggal kita yang didalamnya sudah terdapat nama-nama, sehingga calon anggota baru hanya memilih negara yang sesuai dengan data diri.

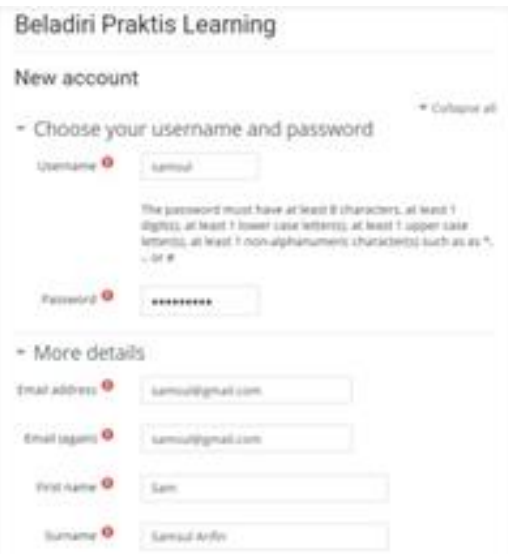

Gambar 16 Halaman Pendaftaran

Halaman utama ini adalah halaman yang pertama kali muncul ketika user berhasil melakukan loginyaitu pada halaman dashboard yang didalamnya berisi kelas kursus yang diikuti oleh user tersebut

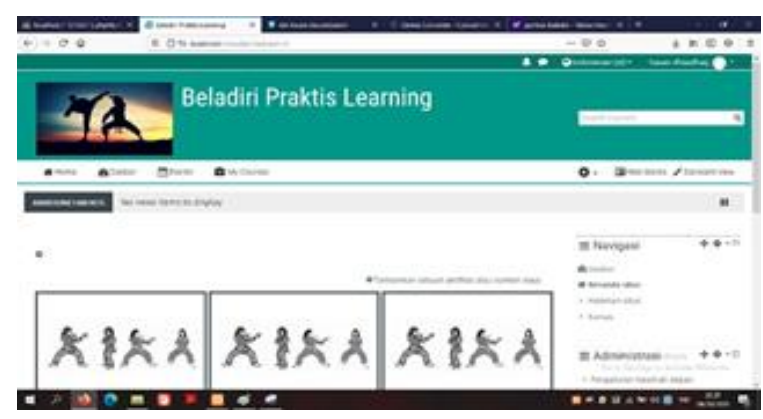

Copyright $\left({ }_{0} 2020\right.$ FT-UHAMKA. - All rights reserved DOI: $10.22236 /$ teknoka.v5i.340

\section{Gambar 17 Halaman Dashboard}

Berikut adalah tampilan pengelolaan kelas yang hanya dapat dilakukan oleh admin saja. Untuk masuk ke halaman ini admin memilih menu administrasi situs, lalu pilih course atau kursus, dan pilih course and category management.

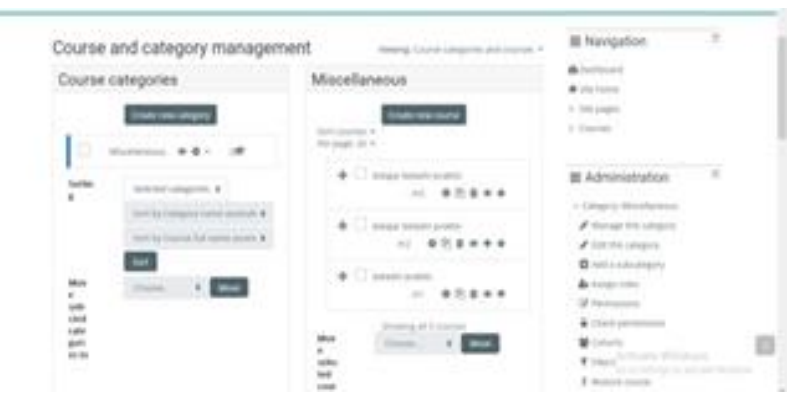

Gambar 18 Halaman mengelola Kelas Pada Admin

Berikut adalah tampilan pengelolaan user yang hanya dapat dilakukan oleh admin saja. Untuk masuk ke halaman ini admin memilih menu administrasi situs, pilih user, lalu pilih akun, dan pilih lihat daftar pengguna atau browse list of user. Pada halaman ini terdapat tabel yang didalamnya berisi data-data user yang sudah mendaftar kedalam sistem tersebut. Pada halaman ini admin dapat menambahkan user secara manual, menghapus user, mengedit data user dan mengkonfirmasi user yang baru mendaftar pada sistem e-Learning.

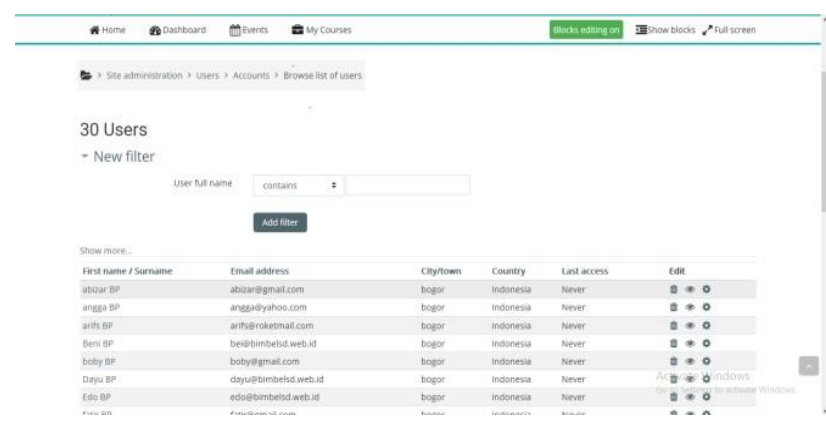

Gambar 19 Tampilan Mengelola User bagi Admin

Berikut merupakan tampilan dari kelas kursus yang muncul ketika user memilih kelas kursus yang terdapat pada halaman utama. Untuk dapat melihat isi materi dari kelas tersebut user dapat memilih materi yang ingin dilihat dengan cara mengklik text link yang terdapat pada kelas tersebut. User dapat mengetahui aktivitas yang sudah dilakukan pada kelas tersebut dengan melihat check box yang terdapat pada setiap materi yang tersedia. Selain 
materi didalam kelas kursus juga terdapat forum diskusi, tugas dan kuis. Tugas dan kuis ini dapat dikerjakan apabila user telah melihat materi yang telah disediakan dikelas tersebut.

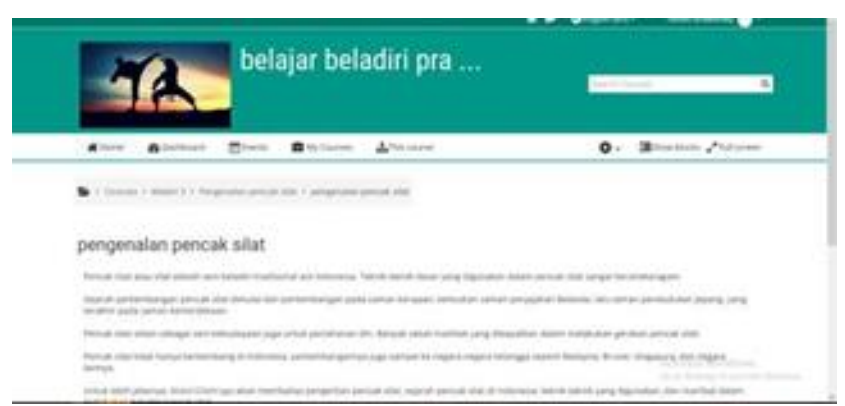

Gambar 20 Tampilan Materi Kursus

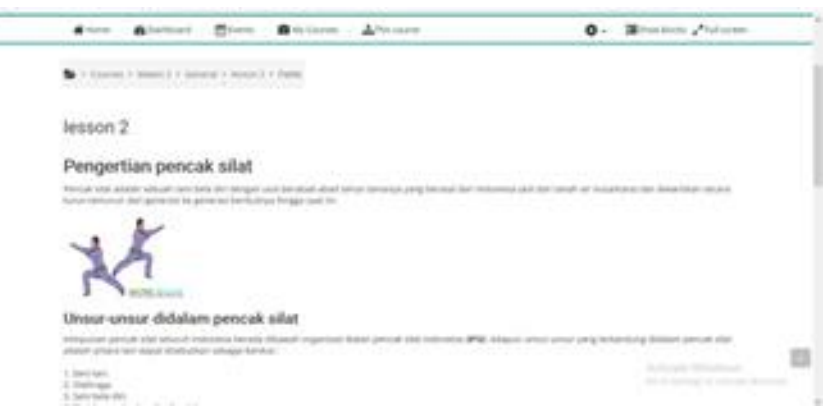

Gambar 21 Tampilan Materi kursus

\section{SIMPULAN}

Sistem Informasi pembelajaran E-Learning beladiri praktis berbasis Moodle telah selesai di buat dan pengujia dari hasil pembuatan e-learning berbasis moodle sesuai dengan program.

\section{KEPUSTAKAAN}

[1] Wordpress, (2011) tapaksuci104sumedang: https://tapaksuci104sumedang.wordpress com/2011/03/31/keilmuan-seni-beladiritapak-suci-sebuah-tinjauan- singkat-2/
[2] Onioni.com, (2020) pengertian E-learning https://www.onoini.com/pengertian-elearning/

[3] Karwati, E. (2014). THE INFLUENCE OF ELEARNING BASED ON INFORMATION. 530, 41-54.s

[4] Zyainuri, Z., \& Marpanaji, E. (2013). Penerapan e-learning moodle untuk pembelajran siswa yang melaksanakan prakerin. Jurnal Pendidikan Vokasi, 2(3), 410-426.

[5] Fatmawati. (2015). J urnal E quilibrium Jurnal E quilibrium. Equilibrium Pendidikan Sosiologi, IV(1), 1-10

[6] Palit, R. V, Rindengan, Y. D. Y., \& Lumenta, A. S. M. (2015). Rancangan Sistem Informasi Keuangan Gereja Berbasis Web Di Jemaat Gmim Bukit Moria Malalayang. E-Journal Teknik Elektro Dan Komputer, 4(7), 1-7.

[7] Firman, A., Wowor, H. F., Najoan, X., Teknik, J., Fakultas, E., \& Unsrat, T. ( 2016). Sistem Informasi Perpustakaan Online Berbasis Web. E-Journal Teknik Elektro Dan Komputer, 5(2), 29-36.

[8] Binarso, Y. A., Sarwoko, E. A., \& Ba, N. bahtiar. (2012). 434-853-1-Sm. Pembangunan Sistem Informasi Alumni Berbasis Web Pada Program Studi Teknik Informatika Universitas Diponegoro, l(1), 72-84. 